\title{
Urgency of Employment Protection Regulation for Online Transportation Driver
}

\author{
I Wayan Gde Wiryawan \\ The Faculty of Law, Mahasaraswati University, Denpasar , Bali-Indonesia \\ gdewiryawan@unmas.ac.id
}

Published: 28/02/2020

How to cite: Wiryawan, I. W. G. 2020. Urgency of Employment Protection Regulation for Online Transportation Driver. Sociological Jurisprudence Journal. 3(1). 34 - 42. https://doi.org/10.22225/scj.3.1.1319.34-42

\begin{abstract}
The phenomenon of online application-based transportation services is actually an answer to people's needs for transportation that is easy to get, convenient, fast, and cheap. There are many factors making this online-based application is needed by many people, especially in big cities in Indonesia. Online transportation has become an alternative mode that people want after previously they have to use the conventional modes. Behind the convenience provided, the presence of GO-JEK and Grab has contradictions from various parties. There are no regulations specifically regulating worker protection for the drivers because in Law Number 13 of 2003 concerning Manpower (hereinafter referred to as the Manpower Law) only regulates formal worker. Thus, worker standards in the Manpower Law cannot be applied to online transportation drivers. The urgency to make rules regarding worker protection for online transportation drivers should be considered by the Government. Therefore, it can create legal certainty and justice for the drivers like the formal workers.
\end{abstract}

Keywords: Employment; Legal Protection; Online Transportation.

\section{INTRODUCTION}

Transportation has a major influence on individuals, the economic development community, and the socio-political state of a country. Transportation is a means and infrastructure for State Economic Development that can encourage the pace of economic growth (Salim, 1993).

The more developed means of transportation, the easier the relationship between humans will be. Since ancient times, human mobility has occurred. Transfer of population from one place to another has occurred. This population mobility is also followed by the mobility of the goods carried by them. Therefore, the means of transportation since the past has been needed by humans. At present, in which the human and goods mobility are very high and occur not only in one region but also between islands and even countries, the means of transportation play an important role. Transportation has a major influence on individuals, the economic development community, and the socio-political state of a country. Transportation is a means and infrastructure for the State Economic Development that can encourage the pace of economic growth.

The phenomenon of online application-based transportation services is actually an answer to people's needs for transportation that is easy to get, convenient, fast, and cheap. Many factors making this onlinebased application is needed by many people, especially in big cities in Indonesia. Online transportation has become an alternative mode that people want after previously people have to use the conventional modes. The conventional transportation reaps a number of problems such as the lack of security and comfort, for example when using public buses which are often not feasible to operate or other factors (Wijaya, 2016)

The sophistication of applications based on both Android and IOS is widely used by individuals who just want to pioneer a business, or for business people as an effort to increase their income in addition to provide convenience for everyone. It can be seen in the increasing number of online travel applications, clothing sales applications, online ticket applications and so on, in which all of them can be downloaded 
through Google Play or App Store, an application feature provider for every Android smartphone or iOS. GO-JEK is one of the pioneers of online application-based transportation services in Indonesia. The presence of GO-JEK is intended to make it easier for anyone who wants to use motorbike taxi services without having to look for a motorcycle taxi driver or go to the motorcycle taxi stand. Pioneer of PT. GO -JEK Indonesia is Nadiem Makarim. Starting in 2010 as a two-wheeled transportation company through telephone calls, GO-JEK has now grown into an application-based transportation and lifestyle service company. In line with GO-JEK, the Grab application is also an online-based transportation provider operating in Indonesia.

GO-JEK and ojek generally have a fundamental equation, namely, when viewed from the type of transportation used, both of them use motorbikes. While the difference which is located in the ordering process, in which for GO-JEK orders, each service user can only order through Android or iOS smartphones. Automatically, GO-JEK directly determines rates calculated based on the distance to the destination, so there is no longer price bargaining as what is done with conventional ojek. GO-JEK motorcycle taxi drivers themselves are managed directly by PT. GO-JEK Indonesia. Since its inception, GO-JEK has stolen the attention of the public. Until now, GO-JEK has spread in various major cities in Indonesia such as Jabodetabek, Makassar, Surabaya, Bali, Solo, Yogyakarta, Balikpapan, Medan, Semarang, Palembang and others. The GO-JEK application offers services such as Go-Ride, Go-Car, Go -Food, GoMart, Go-Glam, Go-Massage, Go-Clean, Go-Box, and the last one to launch is Go -Busway.

With this service, GO-JEK provides two options of vehicle given to consumers, namely 2 -wheeled vehicles (motorcycles) and 4-wheeled vehicles (cars). Such transportation innovation is a new multicreative breakthrough, which is not only a contribution to the development of national transportation, but also creates significant employment opportunities for the people in Indonesia. In addition, with the presence of GO-JEK, it has made it easy for the community in activities (GO-JEK official website).

The transportation in the midst of urban conditions nowadays is often in congestion. In carrying out their business, GO-JEK and Grab in Indonesia as the online transportation service providers have a partnership with all GO-JEK and Grab drivers. The regulation regarding partnerships is contained in written agreements and regulations in electronic agreements. Definition of partnership according to Law No. 9 of 1995 concerning Small Business Article 8 paragraph 1 is "Partnership is business cooperation between small and medium-sized businesses or large businesses accompanied by guidance and business development by medium-sized businesses or large businesses by taking into account the principle of mutual need, reinforcement and profitable".

In reality, there are many consumers who use online transportation services, one of which is Go-Ride or Grab bike. These two services are delivery services to destinations that have been focused on the desired location of the customer. Therefore, the consumers can choose the pick-up location and destination when the customers order GO-JEK or Grab. From this service, it is certainly easier for GOJEK and Grab users to order. Besides, facilitating transportation facilities and other activities such as ordering food from the office or home, GO-JEK and Grab themselves also offer relatively cheap and affordable prices. However in reality, it is undeniable that things such as safety in driving trips on the road is still difficult to realize because of various factors that cause a person feels insecure when driving on the road. One of them is an accident; a motor vehicle accident is still one of the biggest donations in the case of casualties in Indonesia.

Behind the convenience provided, the presence of GO-JEK and Grab gets contradictions from various parties. There are no regulations specifically regulating workers protection for drivers because in Law Number 13 of 2003 concerning Manpower (hereinafter referred to as the Manpower Law) only regulates formal workers. Thus, worker standards in the Manpower Law cannot be applied to online transportation drivers. In Article 1 point 15 of the Manpower Law states that an employment relation or relationship shall be defined as a relationship between an entrepreneur and a worker / laborer based on work or employment agreements, which deals with aspects relating to the job that the worker has to do, the worker's wage, and orders and instructions that the worker has to carry out. Therefore, an employment relationship arises from a work agreement, not a partnership agreement. The definition of the work agreement itself is explained in Article 1 number 14 of the Manpower Law as an agreement made between a worker / laborer and an entrepreneur or an employer. The agreement specifies work requirements, rights and obligations of both sides. Therefore, the agreement between the driver and the 
application provider is a partnership agreement; the Law on Manpower cannot be used as a legal basis. Both parties are bound by an ordinary agreement; this case is subject to the rules of the Civil Code (KUHPer) section of the Agreement. The principle of lex specialis derogat lex generalis does not apply in this case.

At present, online transportation services are regulated under the Minister of Transportation Regulation Number 12 of 2019 concerning the Safety Protection of Motorcycle Users. Through this regulation, the government can set service prices. The regulation also requires that the vehicles used in this service must pass the feasibility test as public transportation. This Permenhub is only an ideal sheet that provides protection for the users of online transportation and has not accommodated specifically regarding worker rights for its drivers. The consequences caused by the existence of a legal vacuum, on matters or conditions that have not or have not been regulated can occur legal uncertainty (rechtsonzekerheid) or the uncertainty of legislation in society which will further result in legal chaos (rechtsverwarring). It means that as long as it is not regulated, it is permissible, as long as there is no clear and regulated procedure; it means that it is not permissible. This condition causes confusion (chaos) in the community regarding what rules should be used or applied. In society, there is no certainty of the rules applied to regulate things or circumstances that occur (Mitendra, 2018). Based on the above problems, this research is analysis urgency of employment protection regulation for online transportation driver.

\section{METHOD}

The method used in this research is a juridical-normative method. Juridical-normative method is used to observe the urgency of employment protection regulation for online transportation driver. There are no regulations specifically regulating worker protection for the drivers because in Law Number 13 of 2003 concerning Manpower (hereinafter referred to as the Manpower Law) only regulates formal worker. This research uses primary and secondary legal materials. The statute approach is also used in this study.

\section{RESULT AND DISCUSSION}

\section{The Existence of Online-Based Transportation Services in Indonesia}

The transportation system is organized with the intention of coordinating the process of movement of passengers and goods by regulating its components, namely infrastructure as media and facilities as a tool used in the transportation process. The form of coordination between transportation components brings together several components including infrastructure, facilities and management systems. The transportation system is carried out with the aim that the process of transportation of passengers and goods can be achieved optimally in a certain space and time with consideration of safety, comfort, smoothness and efficiency over time and costs. The operation of the transportation system is related to the development of a region, which will certainly improve the standard of living of the people in an area. This information system is part of the integration and function of community activities and technological developments (Azis \& Asrul, 2012).

Companies engaged in online application-based transportation services are regulated in Notification Number: UM.3012/1/21/Phb/2015 dated November 9, 2015 issued by the Minister of Transportation of the Republic of Indonesia, Mr. Ignasius Jonan. The Permenhub also regulates that online applicationbased transportation service companies must have licenses subject to Non-Tax State Revenues (PNBP) and these service companies must be Indonesian legal entities. With regard to permits, online application -based transportation service companies do not have business licenses in the field of transportation, but have a trading business license. This is because, in practice, the buying and selling scheme that occurs through application technology is divided into two lines, namely:

a. Direct transactions, namely consumers directly order goods and services to providers of business through application technology, and then goods and services are provided directly from the providers.

b. Transactions through liaison, in which consumers order goods and services to business actors who provide liaison services, and then the business actor places an order to the provider of the business 
that matches the customer's order. Furthermore, the providers of goods and services will deliver goods and services to consumers who order at the beginning (Wijaya, 2016).

Of the two lines, online application-based transportation services are included in the transaction path through the link. Almost all business entities that provide liaison services between consumers and business actors providing goods and services through application technology have the status of a limited liability company. The licenses and requirements that are owned are trading business licenses and company registration marks. The purpose and benefits of the birth of online application-based transportation services are as follows:

a. Practical and easy to use, online application-based transportation services simply use smart phones that already use the Internet and online transportation service applications in it. Therefore, transportation services can be ordered.

b. Transparent, this online application-based transportation service also allows customers to know for sure every information in online transportation services in detail such as driver's names, vehicle numbers, position of the vehicle to be used, travel time, driver's license and so forth.

c. More reliable, the drivers have been registered in this online application-based transportation service company in the form of complete identity and driving equipment in accordance with the Indonesian National Standard (SNI) to minimize the risk of lost for the users of this transportation service.

d. The existence of accident insurance for users and drivers. One of the online application-based transportation services company, GO-JEK, has collaborated with the insurance company Allianz in providing accident insurance protection for users of GO-JEK transportation service.

There are two online transportation application provider companies in Indonesia, namely:

a. GO-JEK

Starting in 2010 as a two-wheeled transportation company through telephone calls, GO-JEK has now grown to be the on-demand mobile platform and the leading application that provides a full range of services such as transportation, logistics, payment, food delivery, and various services on demand. GOJEK is a social-minded technology company that aims to improve the welfare of workers in various informal sectors in Indonesia. GO-JEK activities are based on three core values: speed, innovation and social impact. GO-JEK drivers say that their income has increased since joining as a partner by gaining access to more customers through the application. They also get health and accident benefits, access to financial and insurance institutions, affordable automatic installments, and various other facilities. GOJEK has operated in 50 cities in Indonesia, such as Jakarta, Bandung, Surabaya, Bali, Makassar, Medan, Palembang, Semarang, Yogyakarta, Balikpapan, Malang, Solo, Manado, Samarinda, Batam, Sidoarjo, Gresik, and other major cities and development in other cities in the coming year. (GO-JEK official website, www.gojek.com)

b. GRAB

Grab is a Malaysian technology company based in Singapore that provides applications for public transport services including motorized two-wheeled and 4-wheeled vehicles. Grab is only a technology company that launches applications only and for its own vehicles is a vehicle owned by partners who have joined PT Grab Indonesia. With the Grab application, prospective passengers can easily find drivers to get to their destination, so they do not have to wait a long time to get the transportation needed. Grab was founded in 2011 in Malaysia and the founder of Grab was Anthony Tan with his colleague Tan Hooi. In a short time, the simple goal of transforming into something bigger makes Southeast Asia a better place. Today, Grab has been present in six countries throughout Southeast Asia. (Grab's official website, www.grab.id)

\section{The Mechanism of Running an Online Application of Transportation Services}

This online application based transportation service has 3 important parts, namely:

\section{Application Provider (Electronic System Operator)}

According to the Electronic Information and Transaction Law Article 1 paragraph (6) states that the operation of an electronic system is the use of an electronic system by state administrators, people, 
business entities, and / or communities. An online application-based transportation service provider is an electronic system provider that connects vehicle drivers with service users, which is a core part of the birth of this online application-based transportation service, as an application provider has a key role in success in online application-based transportation services. Application service providers are the link between supply and demand, namely application providers or application companies, drivers, and users of online application-based transportation services.

\section{Driver}

The position of the driver (driver) is an individual who stands alone as the owner of the vehicle or the person in charge of the vehicle used. The drivers take advantage of applications that have been provided by online application provider companies to get orders (orders received will be listed as the destination address, name, mobile number and photo of the service user). After the driver gets all service user data in the application that can be seen from the driver's smartphone, the driver will go to the place where the buyer of the transportation service is located. The drivers have an obligation to provide services in the form of security, safety and comfort. Given that road traffic safety involves many agencies and many stakeholders (stakeholders), it is necessary for a coordination of all stakeholders, so that the handling can be carried out in an integrated, effective, efficient and targeted manner, as mandated in Article 203 paragraph (1), Law LLAJ which says "The government is responsible for ensuring traffic safety and road transportation".

\section{Users of Services or Transportation (consumers)}

Users of online application-based transportation services are people who generally need transportation services that are fast, safe, comfortable and inexpensive. The users of online applicationbased transportation services must first download the application of transportation services in their smartphone, which of course is already connected to the internet network and register services in the form of filling in personal data which will be received and processed by the online transportation service company's server.

GO-JEK and Grab as providers of online-based transportation applications are considered to endanger their customers and violate the provisions of Law Number 22 Year 2009 concerning Road Traffic and Transportation (hereinafter abbreviated as Law LLAJ). Based on Article 47 paragraph (2) of the LLAJ Law, motorized vehicles are grouped by type of motorcycle, passenger car, bus car, goods car, and special vehicle. Furthermore, in paragraph (3) it is explained that motorized vehicles such as passenger cars, bus cars, and goods cars are grouped based on the functions of individual motor vehicles and public motorized vehicles. Furthermore, Article 138 paragraph (3) of the UULAJ states "public transportation of people / goods can only be done by public motorized vehicles". The Ministry of Transportation has received a copy of the decision of the Supreme Court (MA) of the Republic of Indonesia number: $37 \mathrm{P} / \mathrm{HUM} / 2017$ concerning the Material Test of the Minister of Transportation Regulation Number: PM 26 of 2017 concerning the Implementation of People Transportation with Public Motor Vehicles Not in Route. The Ministry of Transportation will obey the principle in responding to the Supreme Court's ruling. In addition, the public can also provide complaints to the Contact Center of the Ministry of Transportation on telephone number 151/021-151 or via email: info151@dephub.go.id (Biro Komunikasi dan Informasi Publik, 2017).

Based on Government Regulation Number 39 of 1980 concerning the Transfer of Forms of Jasa Raharja Loss Insurance Public Company to become a Company (Persero), Traffic Accident Insurance Company and road transport referred to in Article 239 of the LLAJ Law is PT. Jasa Raharja (Persero). However, because motorbikes are not included in the public transportation mode as stipulated in the LLAJ Law, GO-JEK Go-Ride service users are not included in Jasa Raharja's insurance coverage in the event of a road accident. Go-Ride GO-JEK and Grabbike passengers cannot submit insurance claims to PT. Jasa Raharja when experiencing a traffic accident and dies. From the absence of guaranteed safety to the users of his services, PT. GO-JEK and Grab Indonesia are also considered to have violated the provisions of Article 4 letter a of Law Number 8 of 1999 concerning Consumer Protection which states: "consumers have the right to comfort, safety and safety in consuming goods and / or services". Regarding this, then PT. GO-JEK Indonesia has collaborated with PT. Insurance for Allianz Life Indonesia by presenting insurance protection to users of its services, namely in the form of life insurance 
provided to GO-JEK service users, especially GO-JEK passengers via smartphones with Android and iOS operating systems. All users of transportation services through GO-JEK, better known as Go-Ride, are provided with insurance protection for any losses incurred due to traffic accidents that arise when using GO-JEK services, with a view to provide security to GO-service users. The amount of compensation provided is up to Rp. 10,000,000, and for hospital fees up to Rp. 5,000,000, - given by PT GO-JEK Indonesia as a form of responsibility to customers. However, when it is compared to insurance provided by PT Jasa Raharja as a provider of social insurance to the public, it will provide compensation based on RI Minister of Finance Regulation No. 15 and 16 / PMK.10/2017 February 13, 2017, compensation for land / sea / air traffic accident victims (official website https://www.jasaraharja.co.id)

\section{Employment Protection Arrangements for Online-Based Transportation}

In today's national development, what is needed is not only to improve the habits and rules that live in the community into written laws, but more than that. The establishment of laws must be able to find legal rules for human relations in society that are still not established, but are ideals that are desired by society. In economic development, that is carried out in a planned manner as implemented by the Indonesian government today, it is law that must form and herd habits (Sihombing, 2010).

The presence of online motorbikes in recent years has led to the opinion that special regulations are needed to regulate them. The government, along with other stakeholders, also drafted a Ministerial Regulation (RPM) regulating this. The draft regulation is given the title of protection of the safety of motorbike users and drivers for the benefit of the community, easier safety rules for ojek pangkalan (Opang) or conventional ojek and ojek online (Ojol). The regulation is claimed to be the result of the ongoing efforts to pressure Ojol drivers who have been fighting for a legal umbrella for the past three years.

\section{Legal Relationship Between Application Providers And Drivers}

The legal relationship between Gojek Indonesia as an application provider company and drivers is a partnership relationship based on a partnership agreement. Therefore, legal protection of drivers is not protection for workers as well as work agreements, but protection as a party in a partnership agreement. Basically, an agreement must be agreed upon by the parties, including if there is a change, it must also be in agreement. If one party (application provider company) changes the contents of the partnership agreement, then of course there must be approval from the other party. They have to see if there is a clause that says that they agree with any changes that will occur in the future. Even though the drivers do not see the partnership agreement when registering, they will, as the online motorcycle taxi drivers, download the online motorcycle taxi application. For example in the latest GO-JEK application, a partnership agreement is attached (after an application update occurs).

In essence, the GO-JEK partnership agreement states that if someone takes action to electronically click on an agreement on a GO-JEK partnership agreement, access and use the GO-JEK application, it means that he has agreed to the partnership agreement contained in the application. In addition, by agreeing to this partnership agreement, he also agrees if there are changes to the terms and conditions that apply. Further explanation regarding the relationship between application providers and drivers is a partnership relationship because there is no element of wages and orders, so it is not an employment relationship. It is explained the relationship between application providers and drivers based on partnership agreements, namely the general form of a legal relationship between one party and another party on the basis of a partnership agreement. The general provisions of the partnership agreement are Article 1338 in conjunction with Article 1320 of the Civil Code ("Civil Code"). Whereas, special provisions, can refer to the provisions of civil alliances in Article 1618 of the Civil Code. Article 1641 of the Civil Code is the legal relationship of the parties between one partner and another partner by entering a "capital" as "submission" (inbreng). If the relationship between application providers and drivers is a partnership relationship, then Act Number 13 of 2003 concerning Manpower and other laws and regulations in the field of workers do not apply. This is because the laws and regulations in the field of Manpower regulate matters relating to workers and employers.

Agus Mulya Karsona, lecturer in Labor Law at the University of Padjadjaran, Bandung states that there is a fundamental difference between partnership and work relations. Partnership relations are more prioritizing mutualism among the parties. In principle, partnerships place more emphasis on mutually 
beneficial relationships. Position of the parties is equal. It is in contrast to the employer-labor position in the superior-subordinate labor law. Based on this explanation, the legal relationship between the application provider company and the driver is a partnership relationship based on the partnership agreement. Therefore, legal protection of drivers is not protection for workers under a work agreement, but rather protection as a party in a partnership agreement (Hasanah, 2017).

\section{The urgency of establishing labor protection standards for online transportation drivers}

Every worker should have the right to get employment social security protection. But the problem is not all labors automatically get it, including informal workers connected to the digital world such as online transportation driver partners. It is believed that the Government needs to give more attention to informal workers such as online transportation drivers who do not get legal protection such as formal workers as stipulated in the Manpower Act.

Informal economy workers are far from being a homogeneous group or a sector. According to ILO report Global Employment Trends 2014, "informal employment remains widespread in most developing countries even if with different variations," accounting for more than 20 per cent of total employment in Eastern Europe; 70 per cent or more in low-income Andean and Central American countries; and as much as 90 per cent in South and South-East Asia. It is widely acknowledged that in the majority of cases, informality is not a choice but rather a necessity "for those not able to find formal jobs and in the absence of privately or publicly provided social protection". According to WIEGO, informal workers contribute to the overall economy, yet much needs to be done to integrate informal workers into mainstream social protection schemes (that is, beyond short term safety nets or targeted social assistance) (International Labour Organization, 2014).

The Manpower Law that applies is still limited in regulating workers who get jobs from employers. Existing regulations do not accommodate protection for those who do work independently but stay connected with others. The existence of labor regulations that follow technological developments is important because so far not all informal workers have realized the importance of insurance protection.

It must be specifically regulated regarding legal protection for online transportation drivers. As material for consideration, the Government can refer to labor standards as stipulated in the Manpower Act which include: employment relations, welfare guarantees and wage standards.

In establishing legislation, it must be carried out based on the principles of the formation of laws and regulations, which include: clarity of objectives, institutions or appropriate forming officials and suitability between types, hierarchies and applicable material content and usefulness and usability, clarity of formulation and openness. In addition, the content material contained in the laws and regulations must reflect the principles of guardianship, humanity and nationality as well as kinship, mediation, bhinneka tunggal ika (unity in diversity), justice and equality of position in law and government, balance and harmony. The principles of establishing legislation above reflect the good form of legislation. If it is applied in a statutory regulation, a good legislation will be formed in accordance with the principles stated in the law without abandoning the principles of justice. Whereas A. Hamid S. Attamimi states about the formation of good legislation. Attamimi's opinion states that the establishment of appropriate Indonesian legislation is as follows: Indonesian Law; The Principle of the State Based on Law and the Principles of Government based on the Constitution, Other Principles. The establishment of laws and regulations must prioritize clarity of purpose. It means that the objectives of the establishment of laws and regulations must be clear, fulfill the wishes of many people in order to create fair certainty so that they can distribute benefits to all Indonesian people. In addition, the concept of institutions or officials forming legislation must be a credible institution, which is democratically recognized by many people. The formation of legislation must adjust the types, hierarchies, and material content and principles in accordance with the basis of the formation of legislation. The principle is the basis or foundation in determining attitudes and behavior. The principles of establishing legislation constitute the basis for the formation of legislation and policy makers in shaping legislation. All principles must be embedded in the policy makers that will form legislation. In the formation of legislation, of course, it requires a principle or basis in establishing a statutory regulation. In the establishment of NKRI legislation, it must base on Pancasila as the fundamental basis. The concept of the state of Pancasila law is the concept of the original legal state of Indonesia to be the main principle in the formation of 
legislation in Indonesia. The concept of the state of Pancasila law plays an important role in realizing legislation in Indonesia (Indrati, 2007).

\section{BPJS Employment Scheme for online transportation drivers}

In an effort to fulfill its commitment to protect online motorcycle taxi drivers, BPJS Employment has cooperated with Grab Bike which was signed in Cibubur, East Jakarta. "Every motorcycle taxi partner who registers himself to the Grab Bike is automatically registered as a participant in BPJS Employment," said the Head of BPJS Employment Branch Office, Jamsostek Tower, Agoes Masrawi. Until now, as many as 15,000 Grab Bike drivers in Jakarta area have been registered as participants in the BPJS Employment. Since 2017, BPJS Employment has also collaborated with PT. Aplikasi Karya Anak Bangsa (Go-Jek). Up to now, there are 200,000 Go-Jek registered in the Jakarta area. Agoes explained, online motorcycle taxis are one of the job professions with high work risks. Moreover, online motorcycle taxi drivers are classified as independent workers because of the status of work partners of online transportation application companies. That is, they are responsible for the risk of their own work. With a variety of limitations and high occupational risks, online motorcycle taxi drivers need employment social security protection, both from the risk of workplace accidents and death. Agoes added that up to now, 15,000 Grab Bike drivers have become BPJS Employment participants by paying contributions of Rp16,800 for two programs, namely Work Accident Guarantee (JKK) and Death Guarantee (JK). They also can participate in Old Age Guarantee (JHT) by adding Rp. 20,000. Meanwhile, Head of Marketing of BPU (Non-Wage Recipient) BPJS branch Menara Jamsostek, Hazairin Hazan responds to the many benefits received when becoming a BPJS Employment participant. The benefits that can be accepted by participants such as the Co-Marketing program. In this program, BPJS Employment participants can get discounts or discounts at merchants or tenants that have worked together, such as hotel, shopping, transportation tickets, services discount.

This program is a program of cooperation promotion and product sales with BPJS Employment participants, through the use of digital marketing media and business directory BPJS Employment. BPJS Employment describes the protection of vulnerable workers and online motorcycle taxis in world social security. BPJS Employment is a spotlight and gets special attention in the International Social Security Association (ISSA), the Organization of Economic Co-operation and Development (OECD), and the German Ministry of Manpower. BPJS Employment opens the eyes of the international community that there are still workers who need serious attention in social security protection. The event which was attended by 25 ISSA and OECD member countries raised the theme 'The Future of Social Protection'. In his material, Agoes discussed the current situation for workers in the vulnerable worker category, whose numbers are quite high in Indonesia. GN Lingkaran which was initiated by BPJS Employment is one of the breakthroughs in providing protection for workers who fall into this category, in which the number is quite large, especially in urban areas. This condition is also triggered by the rapid development of infrastructure in the city and the lack of employment opportunities in the area of origin, giving rise to their own interest in coming and trying their luck in cities, especially Jakarta. The existence of this new type of economy has been anticipated by BPJS Employment through an employment social security protection program for workers in the Non-Wage Recipient sector (BPU). Workers in this sector can get protection with very affordable contributions, namely Rp. 16,800 for 2 protection programs, JKK, and Death Assurance. The steps of BPJS Employment get appreciation in this forum and will be discussed further to be studied and applied to ISSA and OECD member countries. Because the initiative is in accordance with the spirit of ISSA to ensure the protection of social security for the entire community and the principle of 'No One Left Behind' in the United Nations (Sustanainable Development) program (Kundarsa, 2018).

\section{CONCLUSION}

The existence of an online transportation system makes it easy for people to mobilize from one place to another. There are two online transportation application provider companies in Indonesia, namely GO -JEK and Grab. Both companies have a positive impact on the community and open opportunities for people who want to become company partners as drivers. The partnership relationship between the driver and the application provider company is not regulated in the Manpower Law so that there are no regulations that can provide employment protection for the online transportation partner / driver. The 
government should pay attention to the worker protection for online transportation drivers because their existence is one of the supporters of economic acceleration and national development.

\section{REFERENCE}

Azis, R., \& Asrul. (2012). Pengantar Sistem dan Perencanaan Transportasi. Retrieved from https:// books.google.co.id/books/about/Pengantar_Sistem_dan_Perencanaan_Transpo.html? id $=J_{w X P C g A A Q B A J \& r e d i r}$ esc $=\mathrm{y}$

Biro Komunikasi dan Informasi Publik. (2017). Kemenhub Konsisten Terapkan PM 26 Tahun 2017 Sepenuhnya. Retrieved from dephub.go.id website: http://www.dephub.go.id/post/read/kemenhub-konsisten-terapkan-pm -26-tahun-2017-sepenuhnya

Hasanah, S. (2017). Perlindungan Hukum Bagi Driver Ojek Online. Retrieved from Hukumonline.com website: https://www.hukumonline.com/klinik/detail/ulasan/lt5648cbcfc6ad2/perlindungan-hukum-bagi-idriver-iojek-ionline-i/

Indrati, M. F. (2007). Ilmu Perundangundangan: Jenis, Fungsi, dan Materi Muatan. Retrieved from https:// opac.perpusnas.go.id/DetailOpac.aspx?id=4885

International Labour Organization. (2014). Global Employment Trends 2014: The risk of a jobless recovery. Geneva: ILO. Retrieved from http://www.ilo.org/wcmsp5/groups/public/---dgreports/---dcomm/---pub1/ documents/publication/wcms_233953.pdf

Kundarsa, R. (2018). BPJS Ketenagakerjaan berkomitmen lindungi seluruh ojek online. Retrieved from BPJS Ketenagakerjaan website: https://www.bpjsketenagakerjaan.go.id/berita/22186/BPJS-Ketenagakerjaanberkomitmen-lindungi-seluruh-ojek-online

Law Number 19 Year 2016 concerning Information and Electronic Transactions

Law Number 22 Year 2009 concerning Road Traffic and Transportation.

Mitendra, H. M. (2018). Fenomena dalam Kekosongan Hukum. Journal Rechtssvinding. Retrieved from https:// rechtsvinding.bphn.go.id/jurnal_online/Fenomena Dalam Kekosongan Hukum.pdf

Salim, A. (1993). Manajemen Transportasi. Retrieved from https://onesearch.id/Record/ IOS1.INLISM00000000067338

Sihombing, J. (2010). Peran dan Aspek Hukum dalam Pembangunan Ekonomi. Retrieved from https:// books.google.co.id/books/about/Peran_dan_aspek_hukum_dalam_pembangunan.html? id=2iw6ngEACAAJ\&redir_esc $=\mathrm{y}$

Wijaya, A. (2016). Aspek Hukum Bisnis Transportasi Jalan Online. Retrieved from https://opac.perpusnas.go.id/ DetailOpac.aspx?id=976123 